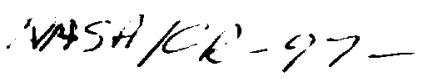

\title{
Numerical Simulation of the 9-10 June 1972 Black Hills Storm Using CSU RAMS
}

\author{
U. S. Nair AND Mark R. HJelmFelt \\ Institute of Atmospheric Sciences, South Dakota School of Mines and Technology, Rapid City. South Dakota \\ Roger A. Pielke Sr. \\ Department of Atmospheric Science. Colorado State University. Fort Collins, Colorado
}

(Manuscript received 28 March 1996, in final form 4 December 1996)

\begin{abstract}
Strong easterly flow of low-level moist air over the eastern slopes of the Black Hills on 9-10 June 1972 generated a storm system that produced a flash flood, devastating the area. Based on observations from this storm event, and also from the similar Big Thompson 1976 storm event, conceptual models have been developed to explain the unusually high precipitation efficiency. In this study, the Black Hills storm is simulated using the Colorado State University Regional Atmospheric Modeling System. Simulations with homogeneous and inhomogeneous initializations and different grid structures are presented. The conceptual models of storm structure proposed by previous studies are examined in light of the present simulations.

Both homogeneous and inhomogeneous initialization results capture the intense nature of the storm, but the inhomogeneous simulation produced a precipitation pattern closer to the observed pattern. The simulations point to stationary tilted updrafts, with precipitation falling out to the rear as the preferred storm structure. Experiments with different grid structures point to the importance of removing the lateral boundaries far from the region of activity. Overall, simulation performance in capturing the observed behavior of the storm system was enhanced by use of inhomogeneous initialization.
\end{abstract}

\section{Introduction}

The 9-10 June 1972 Black Hills storm resulted in the most devastating flash flood in the recorded history of South Dakota. The storm was characterized by convective cells of high precipitation efficiency characteristic of tropical precipitation systems rather than that of a typical midlatitude convective system. The intense precipitation from the orographically forced storm system over the basins of Rapid, Boxelder, Spring, and Battle Creeks (Schwarz et al. 1975) led to severe flooding, resulting in 237 deaths and property damage in excess of $\$ 160$ million (see Fig. 1).

Large-scale features associated with the Black Hills storm and the Big Thompson (Colorado) storm of 1 August 1976, which was similar in nature, are summarized by Maddox et al. (1978). Conceptual models that explain high precipitation efficiency were suggested for the Black Hills storm by St. Amand et al. (1972) and for the Big Thompson storm by Caracena et al. (1979). Dennis et al. (1973) discuss the motion of convective cells observed for the Black Hills storm. Nu-

Corresponding author address: U.S. Nair, Institute of Atmospheric Sciences, South Dakota School of Mines and Technology, 501 East Saint Joseph Street, Rapid City, SD 57701-3995.

E-mail: nair@ias.sdsmt.edu merical simulations of the Black Hills storm were previously made using a two-dimensional, time-dependent cloud model (Kopp and Orville 1973). More recently, mesoscale simulations have been made by Chang and Perkey (1995). Yoshizaki and Ogura (1988) investigated the Big Thompson storm using two- and three-dimensional cloud models. This study focuses on testing the ability of the Colorado State University Regional Atmospheric Modeling System (CSU RAMS) to capture the essential nature and fury of the storm and to examine the various hypotheses for structure and motion of the storm in light of the simulation results.

Section 2 describes the observations of the storm event. The hypotheses about the storm structure for the Black Hills storm (St. Amand et al. 1972) and the Big Thompson storm (Caracena et al. 1979) will be examined in section 3. A brief description of the model initialization is provided in section 4 . The results from the model simulations are described in sections 5,6 , and 7 , and the study is summarized in section 8 .

\section{Observations}

The 0000 UTC surface chart for 10 June 1972 (Fig. 2) shows a polar front to the southeast of the Black Hills region. To the rear, east of the front, a band of moist air with dewpoints ranging from $18^{\circ}$ to $21^{\circ} \mathrm{C}$ can be 


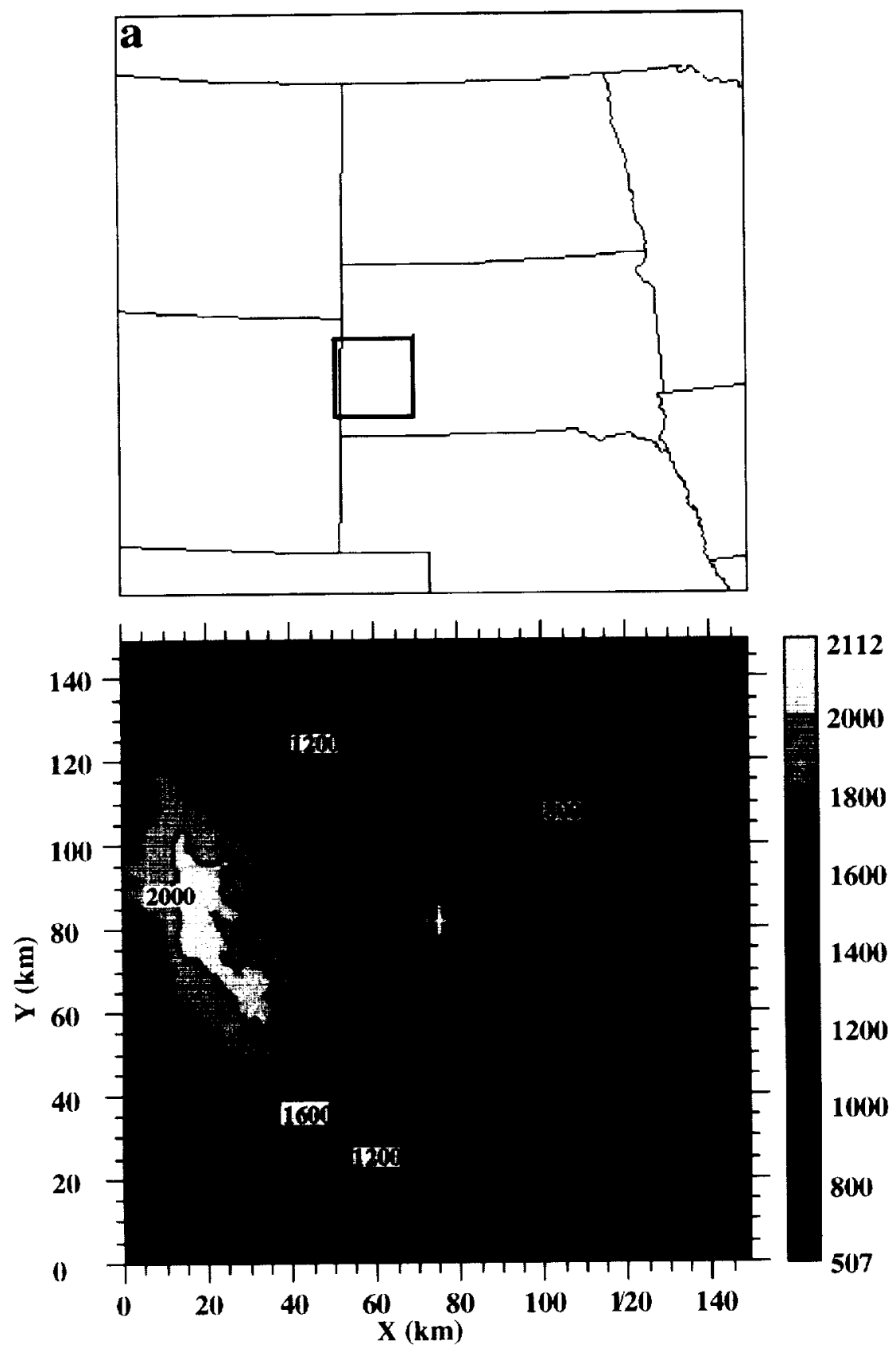

FIG. 1. (a) Location of area affected by the storm; (b) topography for the Black Hills region. Also shown are the major creeks involved in the flooding, and the location of Rapid City is indicated by the cross.

observed. The dominant feature of the wind fields in the surface chart is strong easterlies of $10-15 \mathrm{~m} \mathrm{~s}^{-1}$ to the east of the front.

A strong negatively tilted ridge over South Dakota is the main feature observed on the 0000 UTC $500-\mathrm{mb}$ chart (Fig. 3). A weak trough can be seen approaching the Black Hills region from the southwest. The 0000 UTC 10 June 1972 Rapid City sounding (Fig. 4) shows strong east-southeasterly flow through a deep layer above the surface. The sounding exhibits high instability with a lifted index of -6 . The wind veers to light westerlies in the upper levels. The water vapor mixing ratio in the lower layer is of the order of $14 \mathrm{~g} \mathrm{~kg}^{-1}$. The layer immediately above the surface is conditionally unstable. If the surface air is forced upward, it could become saturated and positively buoyant above $750 \mathrm{mb}$.

The 1200 UTC 9 June 1972 sounding for Huron (figure not shown), which is characteristic of the air mass 


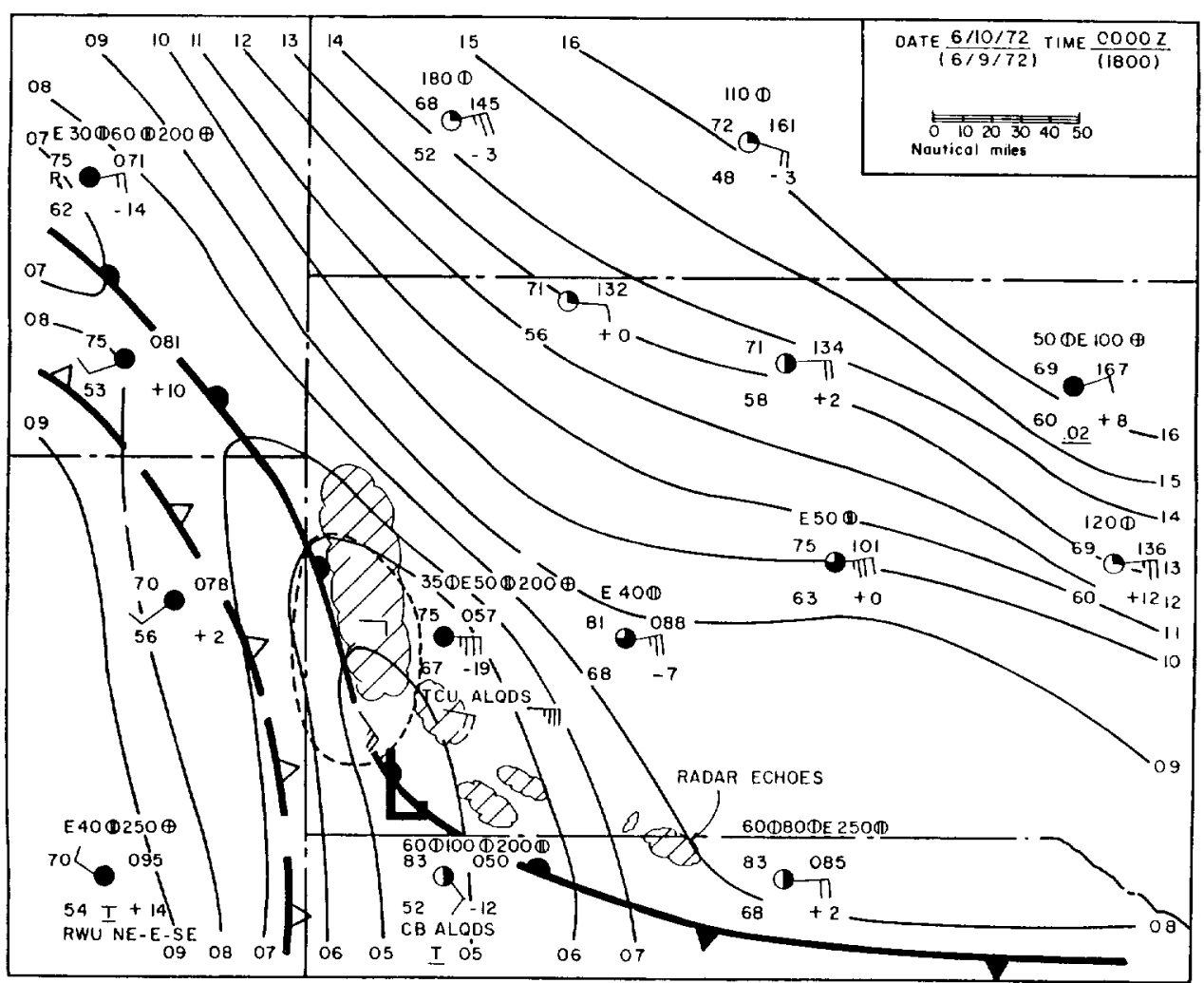

FIG. 2. Surface chart for 0000 UTC 10 June 1972 (Dennis et al. 1973).

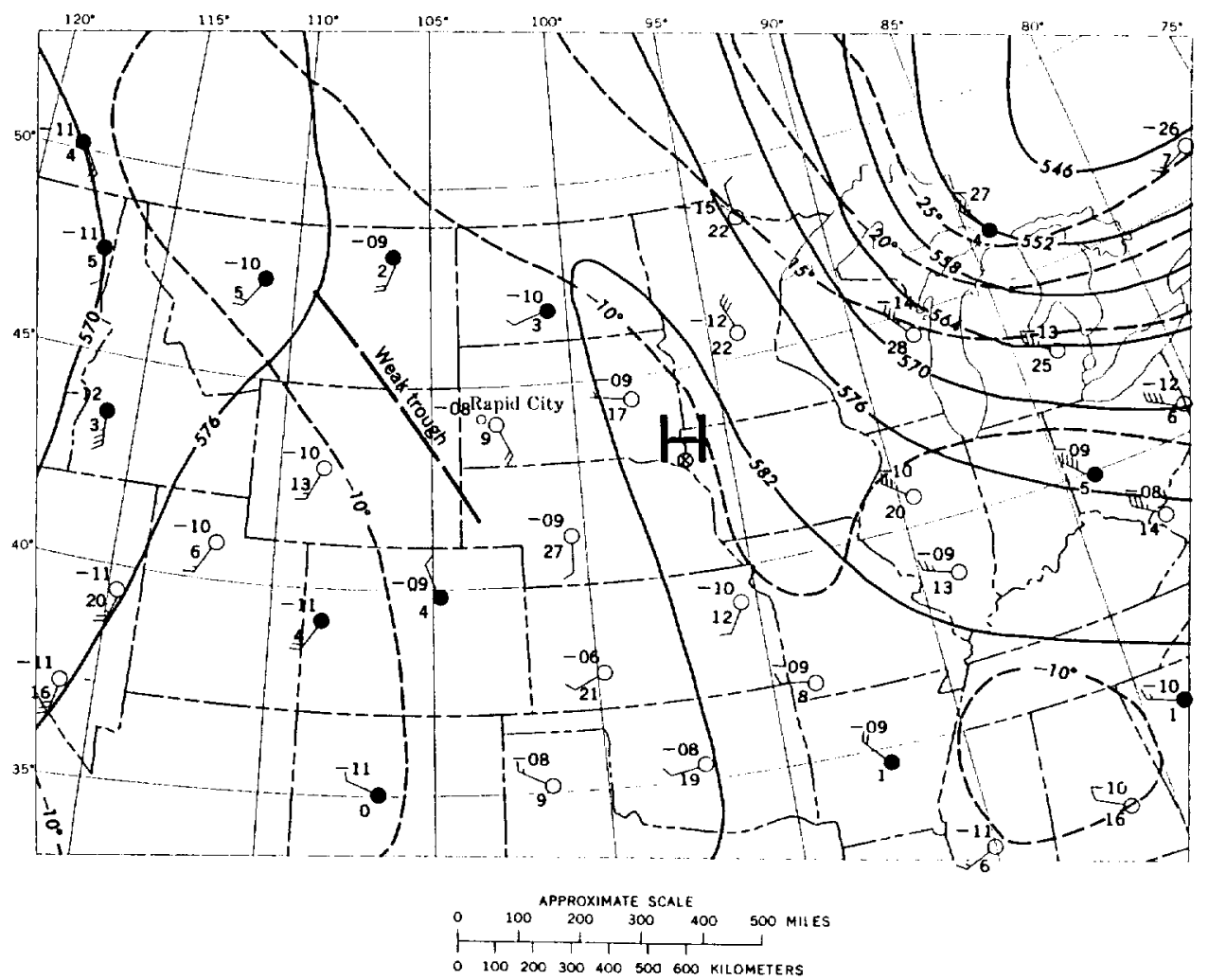

FIG. 3. The 500-mb map for 0000 UTC 10 June 1972 (Schwarz et al. 1975). Bold solid lines are height contours in dekameters and the bold dashed lines are isotherms in degrees Celsius. 


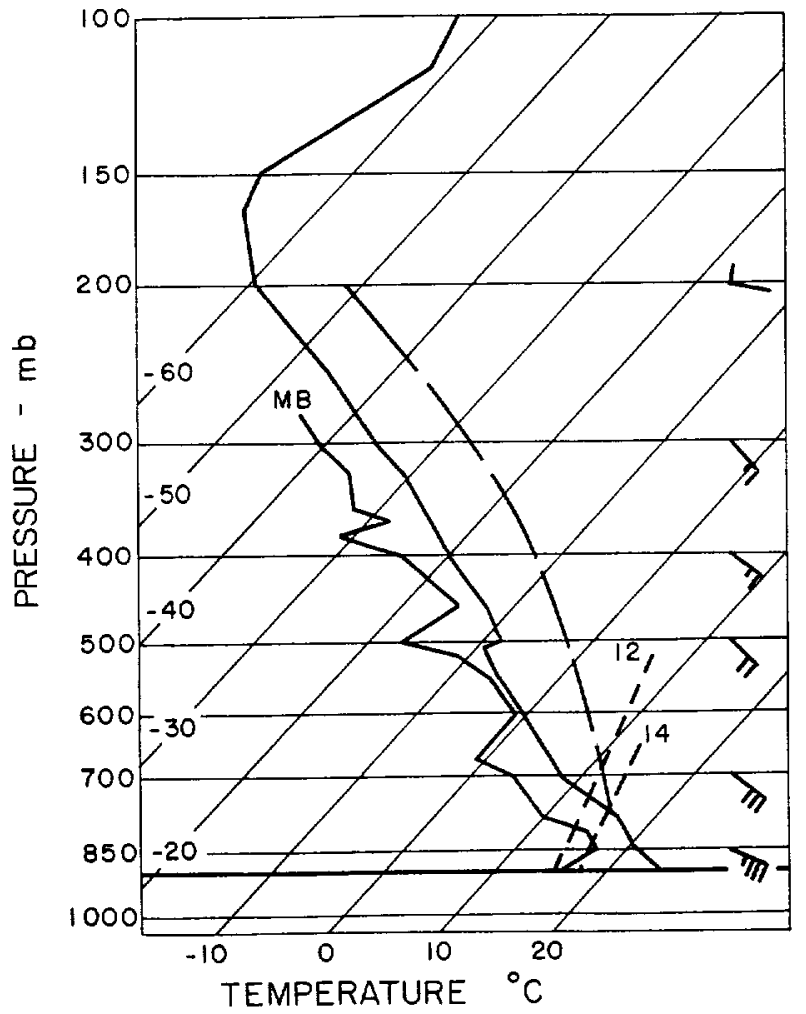

FIG. 4. Rapid City sounding for 0000 UTC 10 June 1972 (Dennis et al. 1973).

to the rear of the front, showed strong temperature inversions. These inversions prevented the release of instability until the air mass experienced lifting over the slopes of the Black Hills. The shortwave trough helped in the release of instability and also, toward the end of the storm event, to flush the convective cells onto the eastern plains.

The track of radar echoes before 0000 UTC (Fig. 5), as observed by a research X-band radar operated by the Institute of Atmospheric Sciences (Dennis et al. 1973), shows cells forming to the south of the Black Hills and moving northwest with time. However, the long-term trend of the radar echoes (Fig. 6) was to remain on the eastern slopes of the Black Hills. Figure 6 is a composite drawing by Schwartz et al. (1975) of significant radar echoes for the period 0000-0700 UTC, based on observations by the National Weather Service (NWS) radar at Huron, South Dakota ( $300 \mathrm{~km}$ east of Rapid City), and the Air Force radar at Ellsworth Air Force Base (15 $\mathrm{km}$ east of Rapid City).

The total accumulated rainfall from the storm event is shown in Fig. 7. The rainfall pattern is aligned in a north-south direction to the west of Rapid City. The maximum observed point accumulation from the storm event was $380 \mathrm{~mm}$. The area of heavy rainfall was restricted to the eastern slopes of the Black Hills, between Rapid City and the central ridge of the hills.

\section{Hypothesis on storm motion and intensity}

Based on these observations, models have been proposed as to the structure of the storm and also the motion of convective cells. Based on radar observations prior to 0000 UTC 10 June, Dennis et al. (1973) suggest a long succession of convective cells moving from the southeast and suddenly intensifying to drop heavy showers on the eastern Black Hills and rapidly diminishing as they continue northwest or north-northwest. Dennis et al. (1973) also note the pronounced absence of downdrafts during the storm event.

Dennis et al. (1973) estimate the precipitation efficiency of the storm system between $80 \%$ and $90 \%$. To account for the high precipitation efficiency of the system, St. Amand et al. (1972) invoke recycling of water substance between mature and newly forming cells. The St. Amand et al. (1972) model (Fig. 8) has a mature cloud mass over the Black Hills due to lifting of moist easterly flow that slopes strongly to the east above 450 $\mathrm{mb}$. Precipitation from the upper sheared region of mature cloud mass is introduced into newly formed cells downstream. This recycling of precipitation enhances the precipitation efficiency of the storm system.

Based on observations from the Big Thompson storm of 1976, Caracena et al. (1979) proposed a conceptual model of the storm structure that would explain the high precipitation efficiency and quasi-steady state. The precipitation efficiency for the Big Thompson storm was estimated to be around $85 \%$. According to Caracena et al. (1979), for orographic convective storms in reverse shear, the strong boundary layer shear underlying weak upper-level winds roots the lower portion of cloud on the mountain. The vertical transport of easterly momentum causes the updraft structure to tilt westward with height. The resulting structure (Fig. 9) allows the precipitation to fall to the rear of the updraft. This enables the updraft to be relatively free of precipitation loading and thus exist in a quasi-steady state.

Numerical simulation of the Black Hills storm by Kopp and Orville (1973) using a two-dimensional timedependent model showed a tendency for the storm to drift over the hills and out of the domain (westward drift). They increased the strength of the upper-level winds, which countered this tendency of westward drift. The numerical simulation of the Big Thompson flood by Yoshizaki and Ogura (1988) showed storm structures similar to that proposed by Caracena et al. (1979). Their experiments using homogeneous initialization of moisture resulted in a region of intense precipitation located at the peak of the terrain, contrary to observations. They also noted the formation of a cold pool underneath the convective cells.

\section{Model description and initialization}

The CSU RAMS is a mesoscale cloud model that has both hydrostatic and nonhydrostatic formulations. In- 


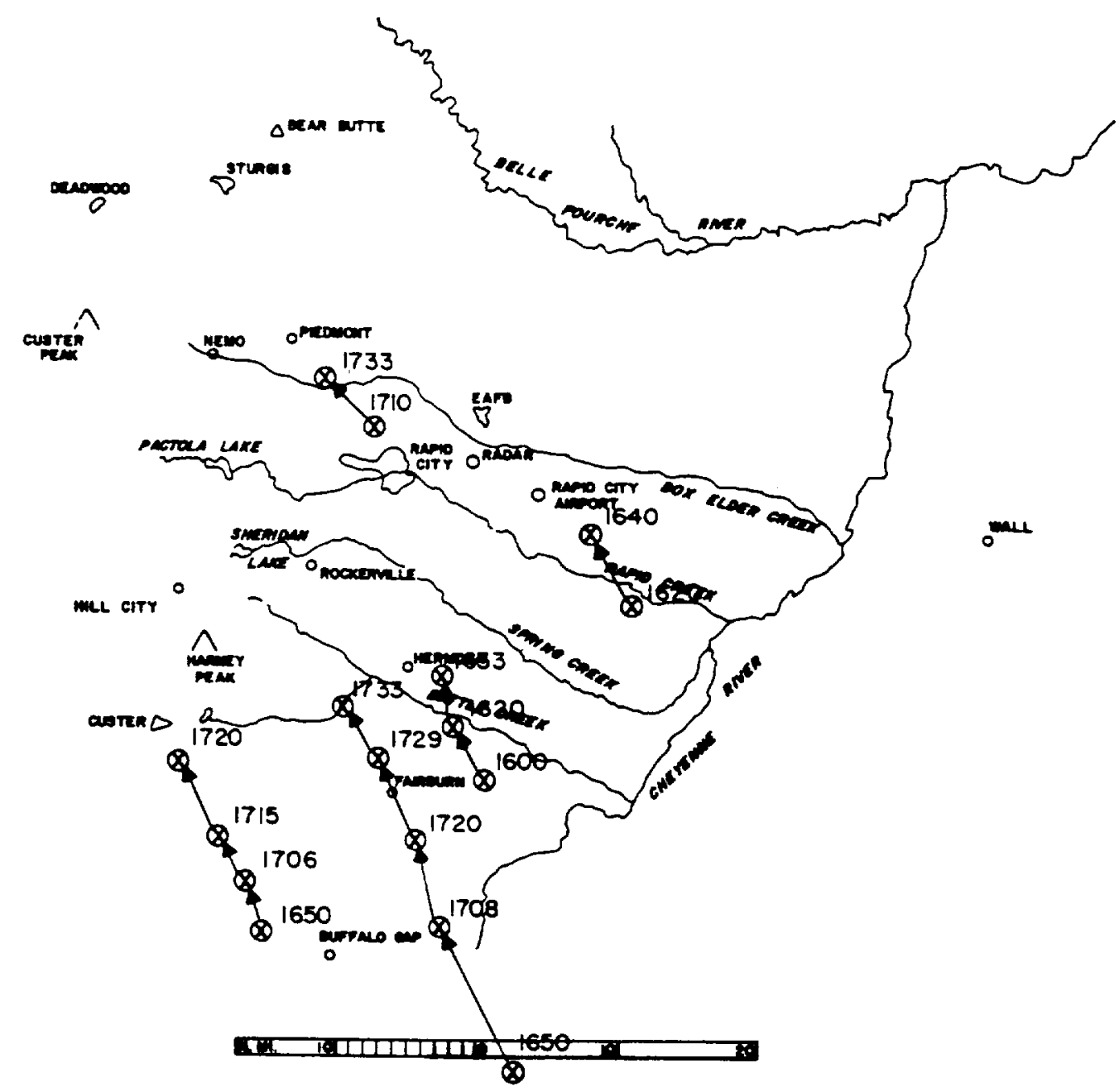

Fic. 5. Track of radar echoes prior to 0000 UTC 10 June 1972 (Dennis et al. 1973).

teractive nested grid structure is available to simulate phenomena that require finer grid spacing. In these simulations, the model utilizes a bulk water parameterization for representing cloud microphysics. A detailed description of RAMS can be found in Pielke et al. (1992).

For the present study, the nonhydrostatic formulation was utilized. Four experiments were performed, three with horizontally homogeneous initialization and one with inhomogeneous initialization. For both modes of initialization, 0000 UTC data were used. The horizontally homogeneous grid used in the first experiment (referred to from here on as HH1) was initialized using the 0000 UTC Rapid City sounding. The model domain (Fig. 7), spanned most of the region of the Black Hills where the greatest amount of precipitation was observed $\left(90 \mathrm{~km} \times 150 \mathrm{~km}\right.$ region centered at $\left.-103.5^{\circ} / 44^{\circ}\right)$. The grid spacing utilized was $1 \mathrm{~km}$ in the horizontal. In the vertical, the grid spacing was $100 \mathrm{~m}$ near the surface, with a grid stretch ratio of 1.15 and maximum vertical spacing of $1 \mathrm{~km}$ above $7 \mathrm{~km}$. The time step used for the horizontally homogeneous simulation was $10 \mathrm{~s}$.
The inhomogeneous initialization experiment (referred to from here on as IH1) utilized a two-way interacting nested-grid configuration. Three grids were used to nest down to the region of interest in the Black Hills. The outermost, coarse-grid spacing (grid 1) of 18 $\mathrm{km}$ covered most of South Dakota and parts of bordering states (North Dakota, Wyoming, Nebraska, Montana). Nested within this grid was a finer grid (grid 2) of $6-\mathrm{km}$ grid interval that covered most of the Black Hills region. The finest grid (grid 3), nested in the second grid, had a grid interval of $2 \mathrm{~km}$ and spanned the region of the Black Hills where most of the precipitation from the storm fell (Fig. 7). The vertical grid spacing for all three grids was $100 \mathrm{~m}$ near the surface, with a grid stretch ratio of 1.2 and maximum grid spacing of $750 \mathrm{~m}$ above $4 \mathrm{~km}$. Variable initialization utilized soundings and surface observations at 0000 UTC from South Dakota and neighboring states. The time steps for grids 1,2 , and 3 were 30,15 , and $5 \mathrm{~s}$, respectively. The model topography was derived from the $30^{\prime \prime}$ U.S. Navy terrain dataset. Figure 10 shows the topography for the horizon- 


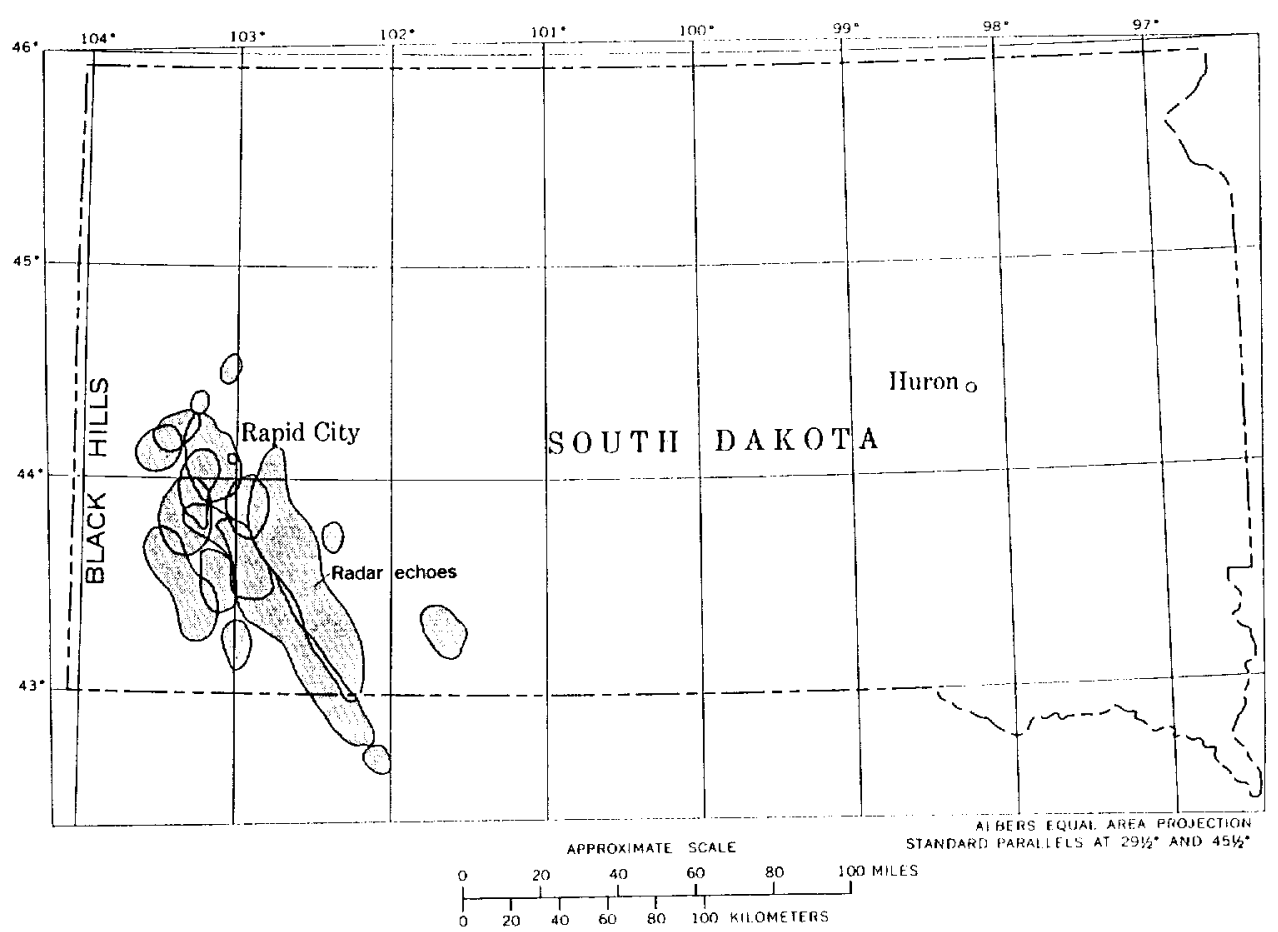

FIG. 6. Composite of radar echoes for the period of 0000-0700 UTC 10 June 1972 (Schwarz et al. 1975).

tally homogeneous (HH1) grid and grid 3 from the inhomogeneous initialization grid. The boundary conditions used for both the $\mathrm{HH} 1$ and $\mathrm{IH} 1$ runs are a rigid-top boundary and the Klemp-Wilhelmson (1978) radiation boundary condition for lateral boundaries. For the inhomogeneous initialization simulation, the nudging option that allows nudging of boundaries toward the next $12-h$ observation was also activated. In the outer two grids for the inhomogeneous initialization run, the microphysical parameterization was not activated and water vapor was treated as a tracer.

Two additional experiments with horizontal-homogeneous initialization were made using the following grid structures: 1) single grid with the same vertical and horizontal structure as that of the innermost grid used in $\mathrm{IH} 1 ; 2$ ) nested grid structure, the same as that used in IH1. These experiments will be referred to from here on as $\mathrm{HH} 2$ and $\mathrm{HH} 3$, respectively. Except for the vertical and horizontal grid spacing, all the other model settings are the same for $\mathrm{HH} 1$ and $\mathrm{HH} 2$. Experiments $\mathrm{HH} 3$ and IH1 differ only in that for HH3 all the grids are initialized using the 0000 UTC Rapid City sounding and the nudging option is not used.

\section{HH1 experiment results}

The model was integrated for $6 \mathrm{~h}$, starting from initial conditions at 0000 UTC. Clouds started developing after 15 min of integration as the moist conditionally unstable air was forced up the slopes by low-level easterly flow.
In early stages of the simulation, clouds form in bands oriented in a north-south direction in the center of the grid. At later times, clouds drift to the left side of the model grid, that is, toward the west. An hour into the simulation, cloud fields start exhibiting a pattern of new cells developing in the southwestern part of model grid with individual cells propagating in a northwest direction. The cells align themselves parallel to the flow. Figure 11 shows clouds at 15 -min intervals starting from an hour of model integration, illustrating this pattern. This pattern of movement persisted throughout the $6 \mathrm{~h}$ of simulation and is reminiscent of radar observations (Fig. 5) reported by Dennis et al. (1973) discussed in section 3. Precipitation is delayed until the cells have reached the higher elevations of the central hills.

The simulated storm system exhibited a precipitation pattern different from that observed. The observed precipitation pattern over the region covered by the grid (Fig. 12b) was oriented north-south approximately symmetric about the center of the grid, while the simulated precipitation pattern is oriented with major axis southeast-northwest (Fig. 12a) and lies in the western region of the grid. The maximum accumulated precipitation at the end of $6 \mathrm{~h}$ was $275 \mathrm{~mm}$, compared to an observed maximum of $380 \mathrm{~mm}$. During the simulation, some of the cells drifted westward and moved out of the model domain. This tendency of westward drift was also noted in a modeling study by Kopp and Orville (1973). The region of intense precipitation for the simulation occurs at the high terrain region, in contradiction to the ob- 


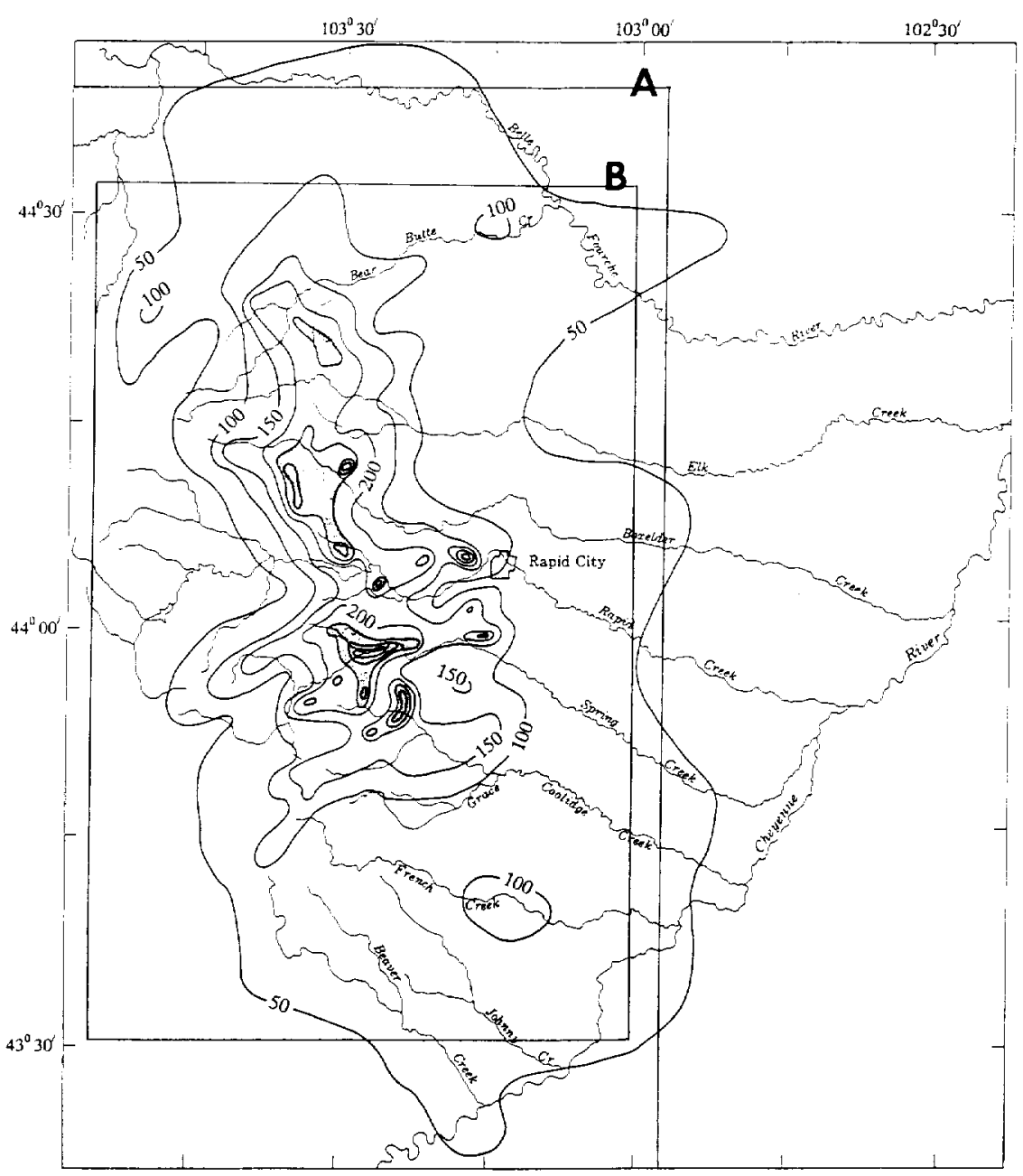

FIG. 7. Total accumulated precipitation for $9-10$ June 1972 for a period of $16 \mathrm{~h}$. Contour interval is $50 \mathrm{~mm}$. Also shown are the locations of the grids used in the experiments. Rectangle labeled $A$ is the location of the grid used in homogeneous initialization $(\mathrm{HH})$, and rectangle labeled $B$ is location of grid 3 in inhomogeneous simulation (adapted from Schwarz et al. 1975).

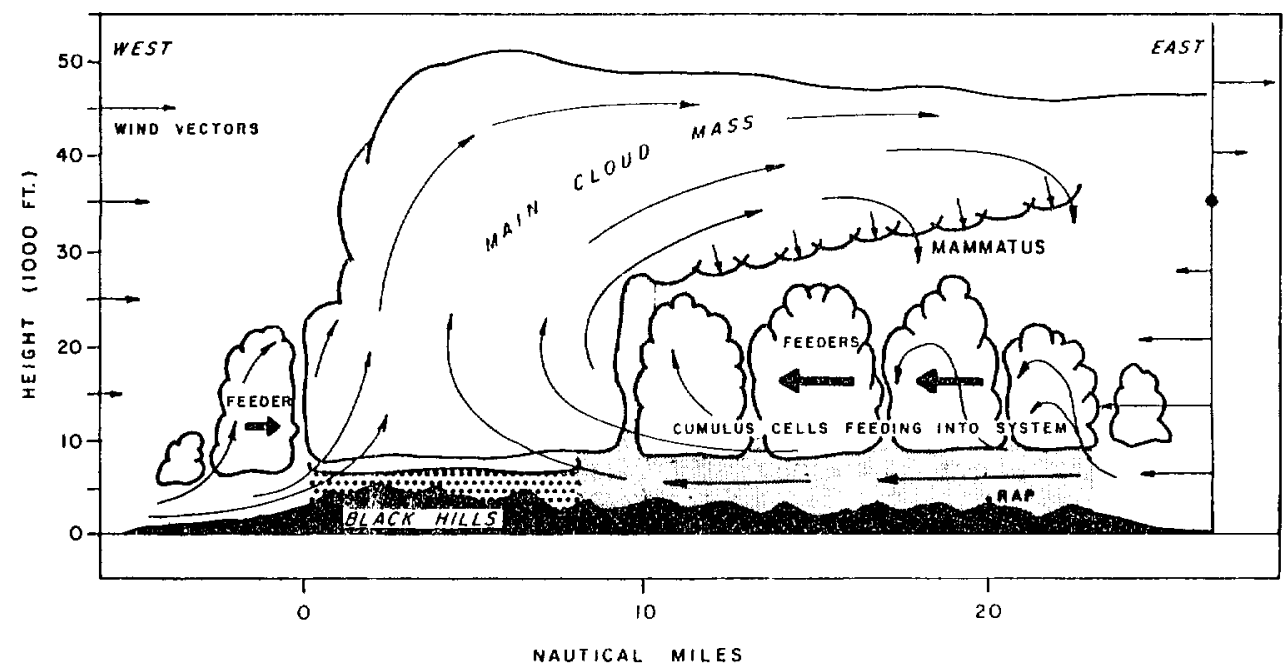

FIG. 8. Conceptual model for storm structure proposed by St. Amand et al. (1972). 


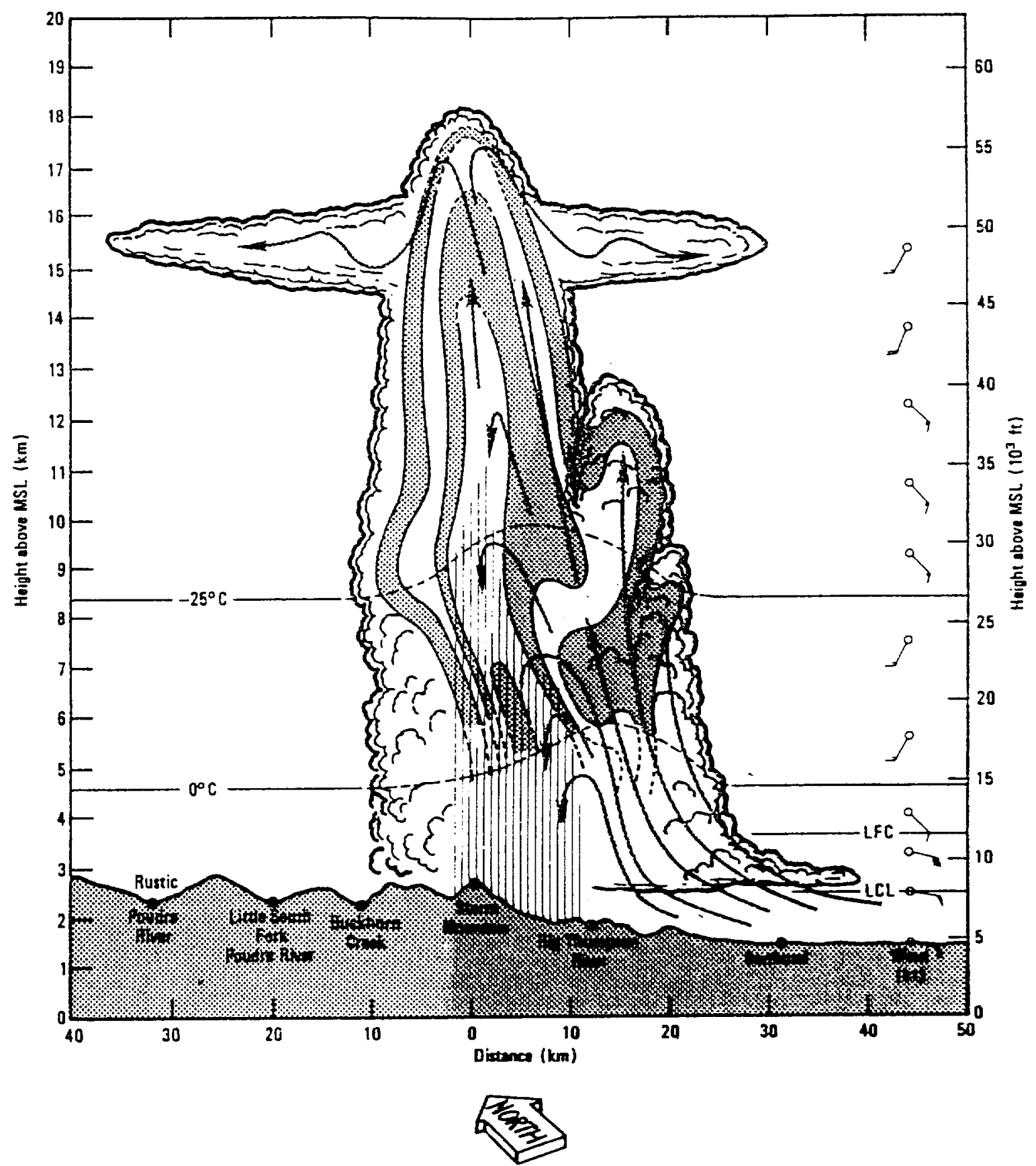

FIG. 9. Conceptual model for the storm structure proposed by Caracena et al. (1979).

servation. Similar results were obtained in the modeling study of the Big Thompson flood by Yoshizaki and Ogura (1988). One of their experiments that had horizontally homogeneous initial distribution of moisture resulted in heavy precipitation occurring at the mountain peak, inconsistent with the observations.

Vertical cross sections through the convective cells (Fig. 13) show an updraft with very little tilt with height. Another interesting feature is the absence of any sig- nificant strong downdrafts or cold outflows, particularly in regions of precipitation shafts. This is consistent with the observations by Dennis et al. (1973) but is in contrast to the cold air pools beneath the storms reported by Yoshizaki and Ogura (1988) in their modeling study of the Big Thompson storm. The lack of downdrafts has been attributed to moist midlevel air and low cloud bases, which restrict evaporative cooling. Model results indicate graupel melting to form rain was an important 

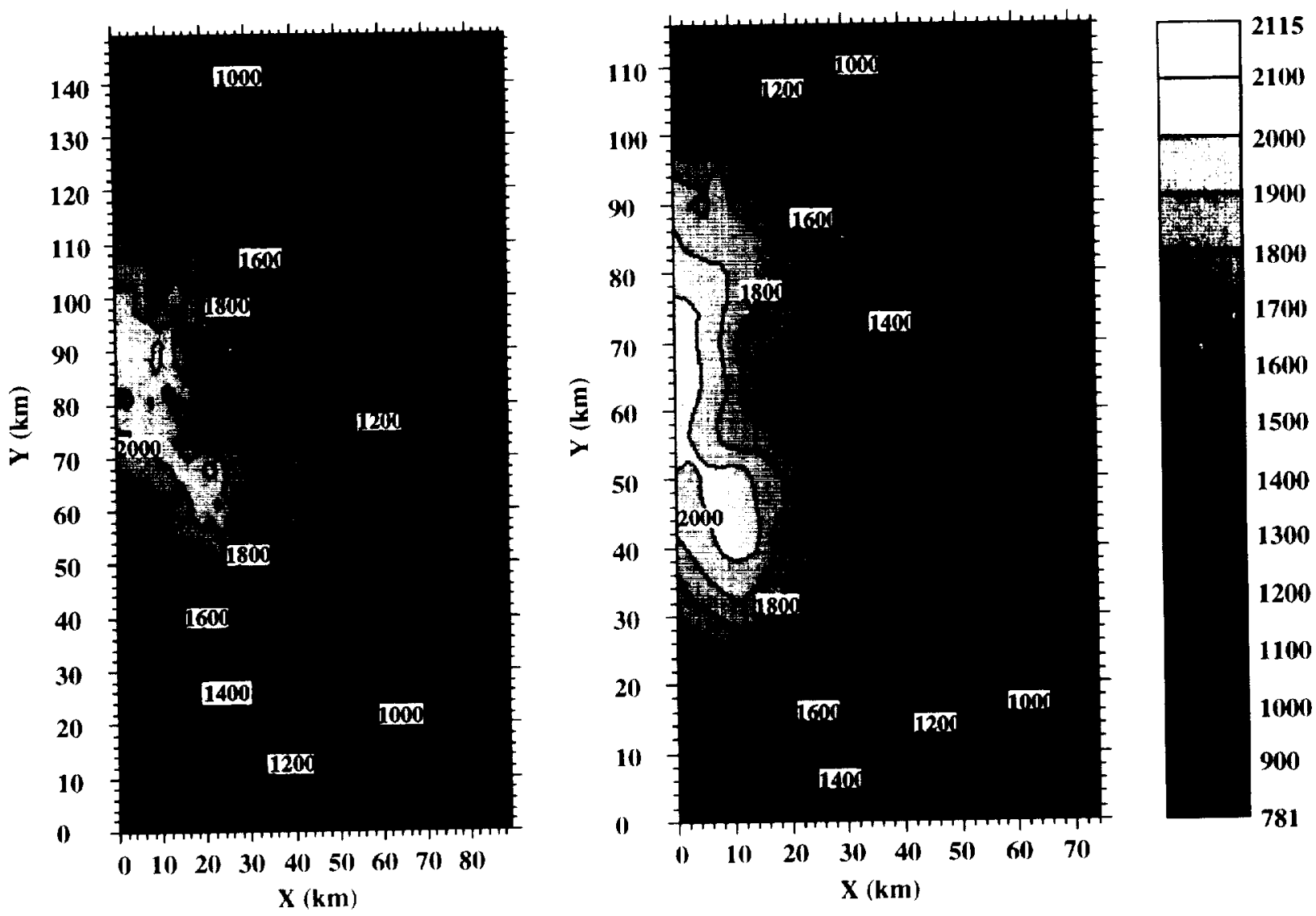

FIG. 10. The topography for (a) HHI and (b) grid 3 of IH1. Contours in intervals of $100 \mathrm{~m}$.

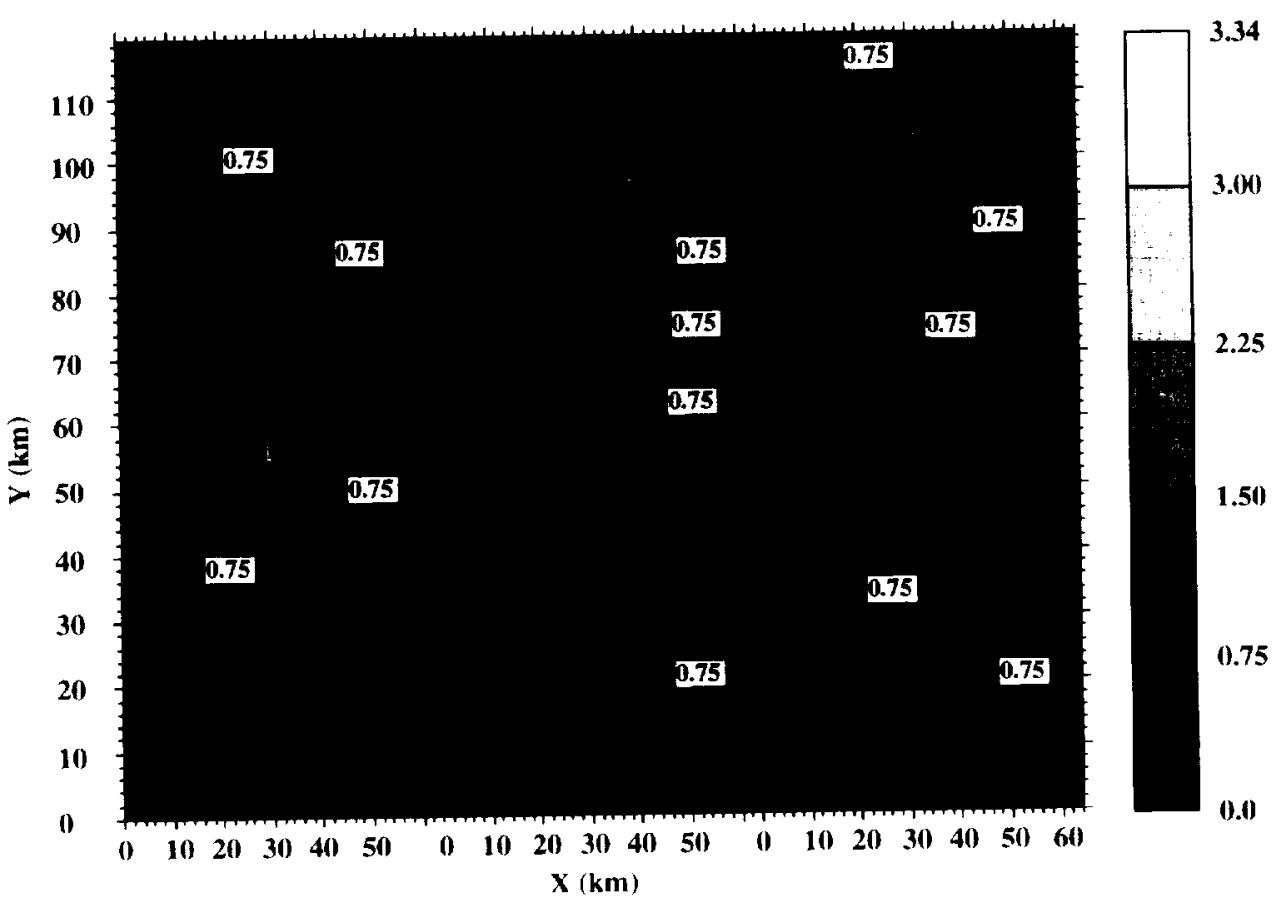

FIG 11. Cloud field at $3.7 \mathrm{~km}$ for the homogeneous initialization at (a) 60 , (b) 75 , and (c) 90 min into the model integration. The contour interval is $0.75 \mathrm{~g} \mathrm{~kg}$ '. 

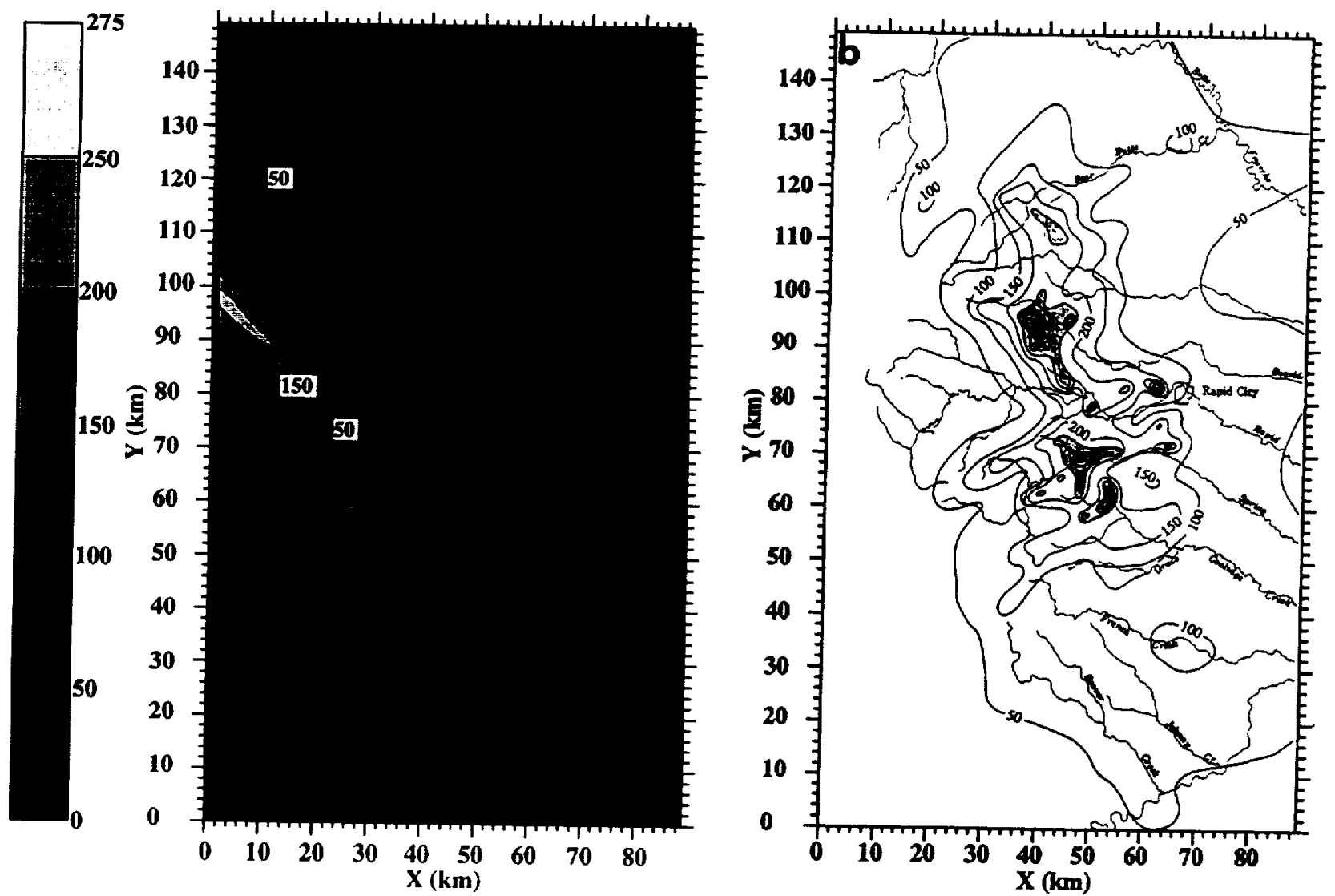

FIG. 12. (a) The 6-h accumulated precipitation for homogeneous model initialization (HHI) in millimeters; (b) total accumulated precipitation from the storm event for the same area in millimeters; (adapted from Schwarz et al. 1975). Contour interval is 50 mm.

microphysical process, but it appears that cooling achieved from the melting process was not strong enough to initiate strong downdrafts.

\section{Inhomogeneous initialization (IH1) experiment results}

The inhomogeneous simulation was integrated for 6 $h$ starting from the initial conditions. Clouds started forming near $30 \mathrm{~min}$ of simulated time, about $15 \mathrm{~min}$ later than in the HH1 simulation. The storm structure and motion were significantly different than for the horizontally homogeneous simulation. The storms formed in the center of the model grid (grid 3 ) in a band aligned in a north-south direction and tended to be stationary. This is consistent with the long-term trend of radar echoes (Fig. 6) discussed in section 2.

The vertical section through the cells (Fig. 14) shows a pattern very similar to the conceptual model proposed by Caracena et al. (1979). A very pronounced tilt of the updraft in the east-west direction with height can be seen. Also, the rainfield overlaid on the vertical velocity field shows the precipitation falling to the rear of the updraft. The IHI simulation lacked any strong down- draft features, but compared to the HH1 simulations it had some regions of weak downward motion.

The accumulated precipitation field for the IH1 simulation compares more favorably with the observed precipitation pattern than did the $\mathrm{HH} 1$ simulation. Most of the precipitation from the simulation is in the eastern half of the domain (Fig. 15a), as is the observed precipitation pattern (Fig. 15b). Also, the simulation succeeds in approximating the locations of "hot spots," or areas of most intense precipitation. The maximum 6-h accumulated precipitation for the $\mathrm{IHI}$ is $220 \mathrm{~mm}$.

\section{HH2 and HH3 experiment results}

The $\mathrm{HH} 2$ and $\mathrm{HH} 3$ experiments were conducted to investigate substantial differences between the $\mathrm{HH} 1$ and IH1 experiments. In the $\mathrm{HH} 2$ simulation (single grid but with a larger grid spacing, similar to that in grid 3 for the nested cases), the cloud patterns and motion were similar to that of $\mathrm{HH} 1$. The general pattern of 6 -h accumulated precipitation field (Fig. 16a) was similar to that obtained for the HH1 experiment. The magnitude, however, was very different. The maximum value of the 


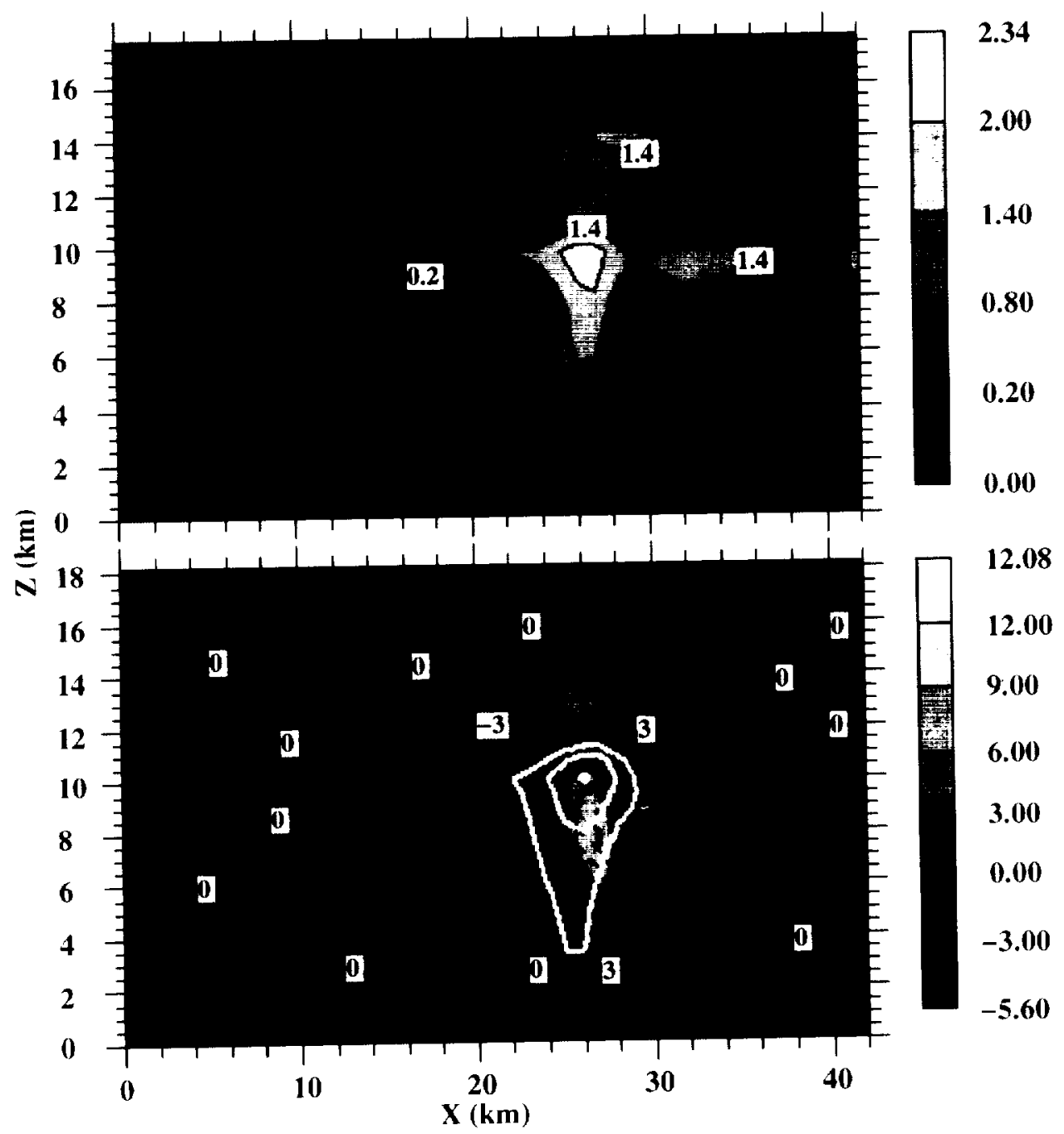

FIG. 13. East-west cross sections at $55 \mathrm{~km}$ from southern boundary of (a) cloud field, contour interval of $0.8 \mathrm{~g} \mathrm{~kg}$. (b) vertical velocity, rain mixing ratio (contours in white) and wind vectors for $\mathrm{HH} 1120 \mathrm{~min}$ into the simulation. The rain mixing ratio contour interval is $0.3 \mathrm{~g} \mathrm{~kg}$ ' and the contour interval for vertical velocity field is $3 \mathrm{~m} \mathrm{~s}$.

6-h accumulated precipitation for $\mathrm{HH} 2$ was $106 \mathrm{~mm}$, compared to $275 \mathrm{~mm}$ obtained for the $\mathrm{HHI}$ experiment.

The HH3 experiment utilized the nested grid of IH1 but with a homogeneous initialization. The nature of cloud patterns for the HH3 experiment was very similar to that of IH 1 . The 6 -h accumulated precipitation pattern (Fig. 16b) was oriented in a north-south direction, similar to the $\mathrm{IH} 1$ experiment results. Experiments $\mathrm{IH} 1$ and HH3 have different values of maximum accumulated precipitation. The $\mathrm{HH} 3$ experiment has a maximum value of $305 \mathrm{~mm}$, compared to $220 \mathrm{~mm}$ obtained for the IH 1 experiment. The HH3 experiment, however, concentrates the precipitation to a single maximum, compared to four local maxima for the IH 1 experiment. The precipitation field of the IH 1 experiment compares better with the observed precipitation pattern in that respect.

\section{Conclusions}

Based on comparison of the observed and simulated precipitation patterns, it could be concluded that the inhomogeneous simulation (IHI) performed better than the horizontally homogeneous simulations. Both types of simulations rule out the St. Amand et al. (1972) conceptual model for the structure of the Black Hills 9 June 1972 storm. The IH 1 simulation results strongly support the conceptual model suggested by Caracena et al. (1979) for the Big Thompson flood storm structure as also being applicable to the Black Hills storm. Homogeneous simulation results are consistent with early observations (before 0000 UTC 10 June 1972) of the cell motions reported by Dennis et al. (1973), but the longterm trend of radar echoes is more consistent with the IH1 simulation. 


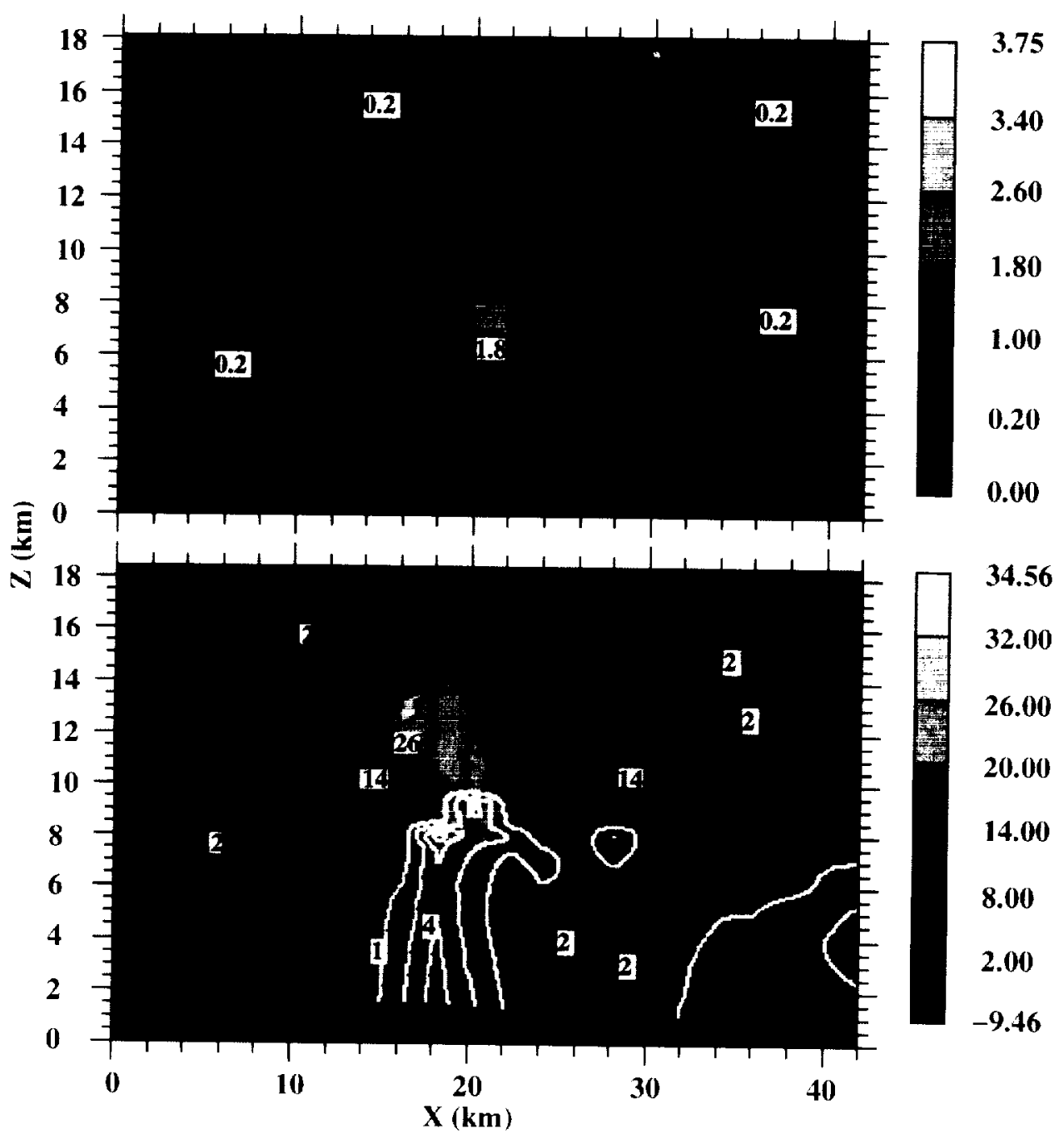

FIG. 14. East-west cross sections at $90 \mathrm{~km}$ from the southern boundary of (a) cloud field. contour interval of $0.8 \mathrm{~g} \mathrm{~kg} \mathrm{'.} \mathrm{(b)} \mathrm{vertical} \mathrm{velocity,} \mathrm{rain} \mathrm{mixing} \mathrm{ratio} \mathrm{(contours} \mathrm{in} \mathrm{white)} \mathrm{and} \mathrm{wind} \mathrm{vectors} \mathrm{for} 1 \mathrm{HI} 120 \mathrm{~min}$ into the simulation. The rain mixing ratio contour interval is $1.5 \mathrm{~g} \mathrm{~kg} '$ and the contour interval for vertical velocity field is $6 \mathrm{~m} s$ ।

In our preliminary study (Nair et al. 1995), we attributed the differences between the simulations $\mathrm{HH} 1$ and $\mathrm{IH} 1$ to differences in the spatial distribution of moisture between the two initializations. It was proposed that IHI succeeded in including the air mass to the east of the Black Hills, thus incorporating the characteristics of air mass in which the storm actually developed after 0000 UTC 10 June 1972. The experiments HH2 and $\mathrm{HH} 3$ were conducted to investigate the effect of boundary conditions and grid spacing on the solution. The $\mathrm{HH} 2$ grid, which has the same structure as that of the innermost grid of the IH1 nested grid, showed similar behavior to the $\mathrm{HH} 1$ experiment. The larger grid spacing used in $\mathrm{HH} 2$ resulted in lower values of 6-h accumulated precipitation. Thus, the difference in grid spacing cannot explain the differences in the nature of evolution of storms in the $\mathrm{HH} 1$ and $\mathrm{IH} 1$ experiments. The $\mathrm{HH} 3$ ex- periment, which has the same nested grid structure and boundary conditions as the $\mathrm{IHI}$ experiment (except for nudging), resulted in storm evolution and a precipitation pattern similar to that obtained in IH1. This would imply that the differences between $\mathrm{HH} \mathrm{l}$ and $\mathrm{IH} \mathrm{l}$ are primarily due to the differences in boundary conditions. The nested grid structure, which moves the artificial lateral boundary away from the region of interest, provides results in better agreement with the observations. The pattern of the precipitation field from the $\mathrm{IHI}$ experiment provides the best match with the observed precipitation field. However, the maximum values of accumulated precipitation for the $\mathrm{HH} 3$ simulation are closer to the observations. Since the spatial distribution of precipitation is important for flood events, and the magnitude of accumulated precipitation from the IH1 simulation is high enough to cause flooding (Kenner et al. 

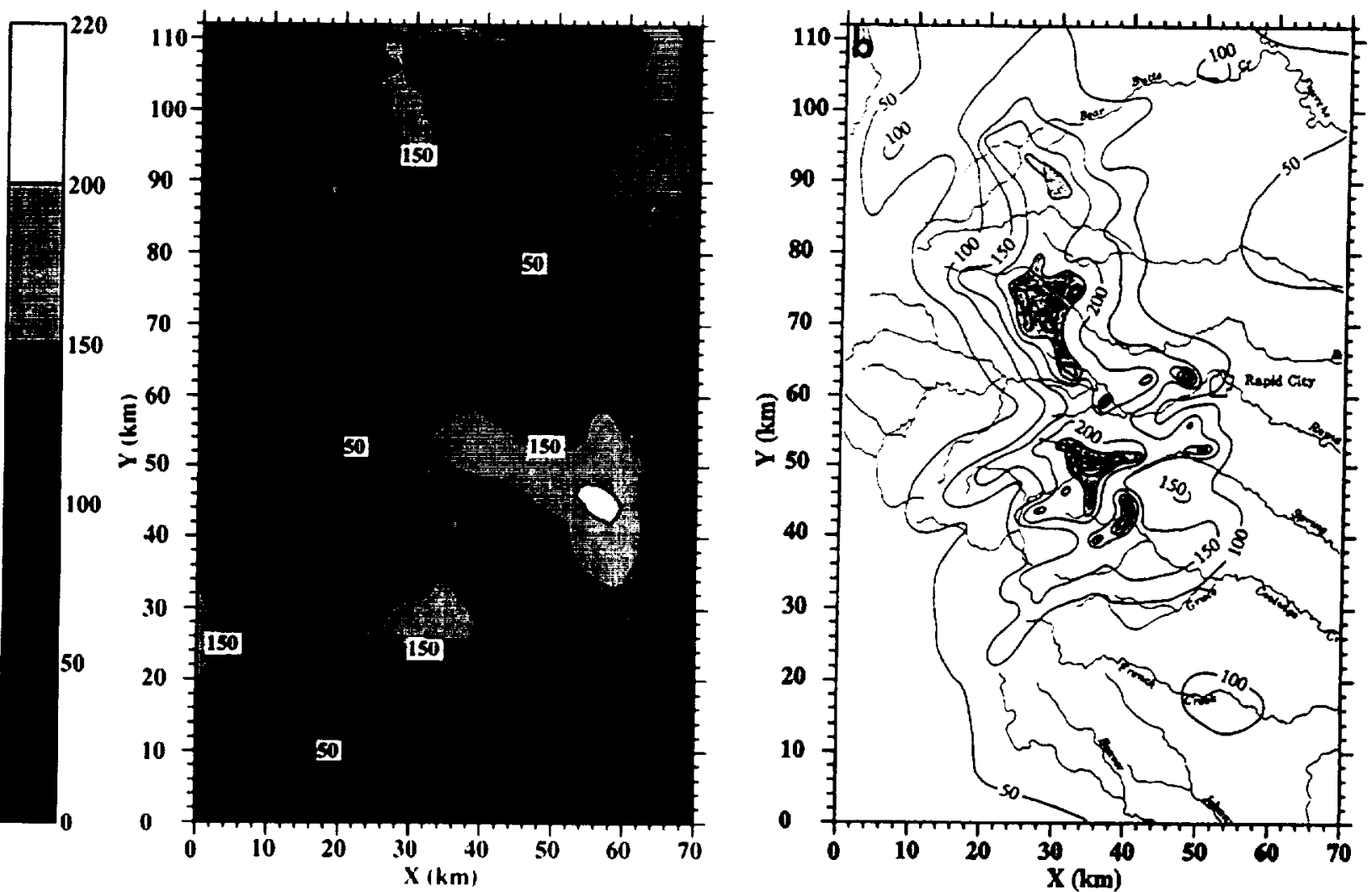

FIG. 15. (a) The 6-h accumulated precipitation for the IHI simulation in millimeters: (b) total accumulated precipitation from the storm event for the same area in millimeters: (adapted from Schwarz et al. 1975). Contour interval is $50 \mathrm{~mm}$.
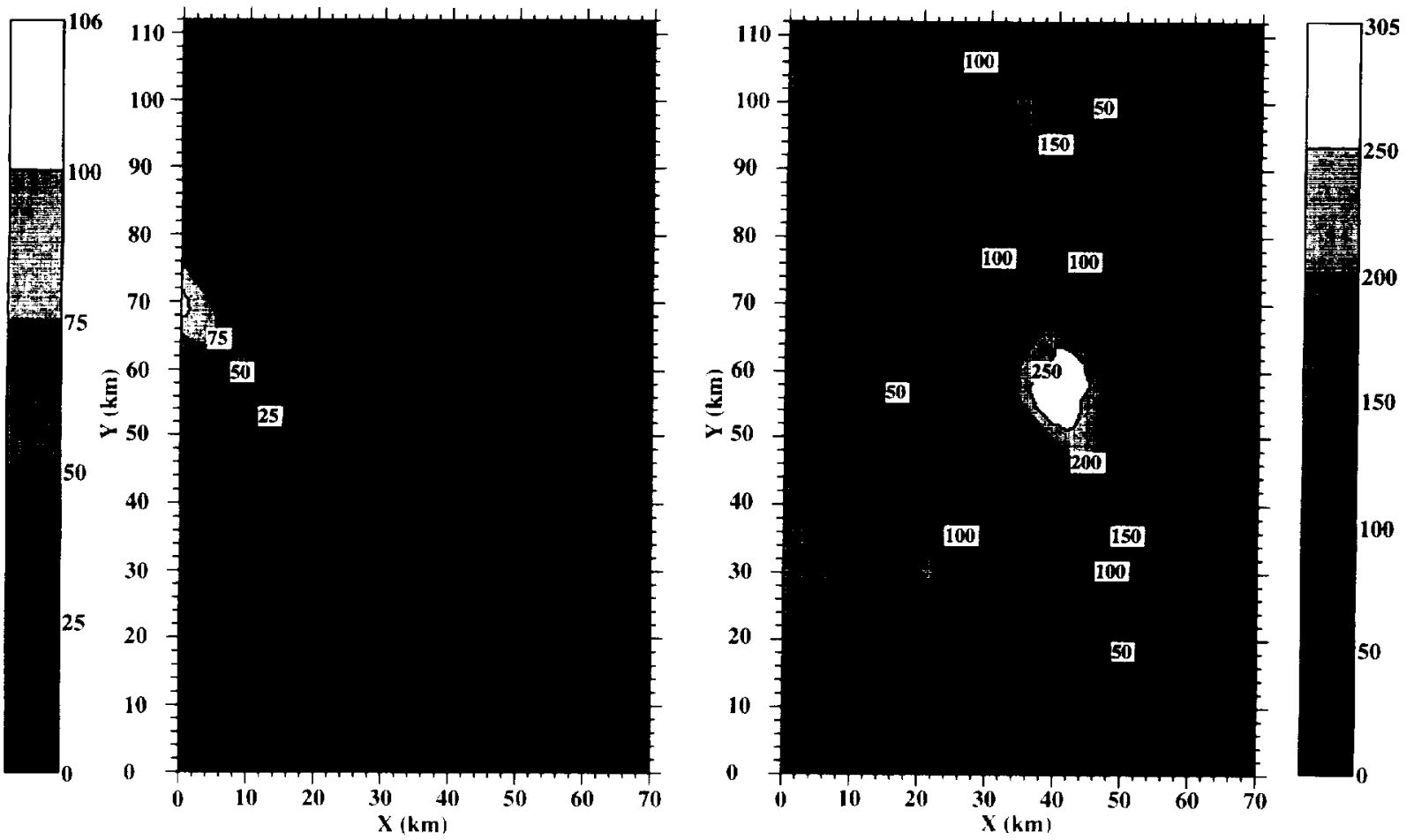

FIG. 16. (a) The 6-h accumulated precipitation for the HH2 simulation in millimeters, contour interval of 25 mm; (b) same for HH3 simulation, contour intervals in $50 \mathrm{~mm}$. 
1996), we conclude that the IH1 simulation compares most favorably with observations. Inhomogeneous initialization with nested grid structure is preferred for good predictions in situations similar to the present study.

Acknowledgments. This work was supported by the National Science Foundation under Grants ATM9123360 and OSR-9452894 and by the South Dakota Future Fund at SDSMT; ATM-9306754 at CSU; and by the National Aeronautics and Space Administration under Grant NAG-1-542. We also thank Ms. Connie Crandall for her assistance in preparing the manuscript, and also Mr. Richard Farley for his assistance in reviewing the manuscript and preparing some of the figures.

\section{REFERENCES}

Caracena, F., R. A. Maddox, L. R. Hoxit, and C. F. Chappell, 1979: Mesoanalysis of the Big Thompson storm. Mon. Wea. Rev., 107, $1-17$.

Chang. C.-B., and D. J. Perkey, 1995: Numerical simulations of mesoscale flood environment. Meteor. Atmos. Phis., 55, 17-32.

Dennis, A. S., R. A. Schleusener, J. H. Hirsch, and A. Koscielski. 1973: Meteorology of the Black Hills flood of 1972. Report 73-4, $41 \mathrm{pp}$. [Available from Institute of Atmospheric Sciences, South Dakota School of Mines and Technology, 501 East Saint Joseph St., Rapid City, SD 57701.]

Kenner, S. J., S. Brich, Y. Yang, M. R. Hjelmfelt, U. S. Nair, and R.
A. Pielke Sr., 1996: Atmospheric and surface hydrologic simulaton of an extreme flood event. Preprints, Second Int. Scientific Conf. on the Global Energy and Water Cycle, Washington, DC, Global Energy and Water Cycle Experiment, 17-18.

Klemp, J. B., and R. B. Wilhelmson, 1978: The simulation of threedimensional convective storm dynamics. J. Atmos. Sci., 35, 1070-1096.

Kopp, F. J., and H. D. Orville, 1973: A numerical simulation of the 9 June 1972 storm in the Black Hills. Preprints, Eighth Conf. on Severe Local Storms, Denver, CO. Amer. Meteor. Soc., 287292.

Maddox, R. A., L. R. Hoxit. C. F. Chappell, and F. Caracena, 1978 Comparison of meteorological aspects of the Big Thompson and Rapid City flash floods. Mon. Wea. Rev., 106, 375-389.

Nair, U. S., M. R. Hjelmfelt, and R. A. Pielke, 1995: Numerical simulation of 9-10 June 1972 Black Hills storm using CSU RAMS. Preprints, Seventh Conf. on Mountain Meteorology, Breckenridge, CO, Amer. Meteor. Soc., 51-56.

Pielke, R. A., and Coauthors, 1992: A comprehensive meteorological modeling system-RAMS. Meteor. Atmos. Phys., 49, 69-91.

Schwarz, F. K.. L. A. Hughes, E. M. Hansen, M. S. Petersen, and D. B. Kelly, 1975: The Black Hills-Rapid City flood of June 910, 1972: A description of the storm and flood. Geological Surveyers Professional Paper 877, $45 \mathrm{pp}$. [Available from Institute of Atmospheric Sciences, South Dakota School of Mines and Technology, 501 East Saint Joseph St., Rapid City, SD 57701.]

St. Amand, P., R. J. Davis, and R. D. Elliott, 1972: Report on Rapid City flood of 9 June 1972. South Dakota Weather Commission, Pierre, SD, 37 pp. [Available from Institute of Atmospheric Sciences, South Dakota School of Mines and Technology, 501 East Saint Joseph St., Rapid City, SD 57701.]

Yoshizaki, M., and Y. Ogura, 1988: Two- and three dimensional modeling studies of the Big Thompson storm. J. Atmos. Sci., 45, $3700-3722$. 